stereo-chemistry in the University of Cambridge; Mr. F. B. Richards, chairman of Woodall-Duckham Company ; Mr. J. Shearman, road motor engineer, L.M.S. Railway ; Mr. T. E. B. Young, general manager, Bolsover Colliery Company; Mr. W. A. Macfarlane (secretary); and Dr. F. S. Sinnatt, director of fuel research (Department of Scientific and Industrial Research), and Mr. J. A. Brook, Mines Department, assessors.

\section{Bibliography of the British Fauna and Flora}

ONE of the difficulties facing anyone wishing to study a group of British animals or plants is that of obtaining reliable information on books and papers that will be helpful in their identification. The Association for the Study of Systematics in Relation to General Biology, one of the aims of which is to encourage wider and more serious studies in systematics, therefore decided to compile a bibliography on the subject. This laborious task has been accomplished with the help of various experts, mainly of the British Museum (Natural History) and the Royal Botanic Gardens, Kew, and the book is expected to appear shortly. It contains systematically classified lists of books and papers which may be consulted when studying any given group of British animals or plants. Brief notes on the character and contents of each book and paper are given, so that an idea can be formed as to whether it answers any particular requirements. The whole forms a most useful guide for systematic studies and is certain to achieve its purpose of stimulating scientific interest in the British fauna and flora. Further information can be obtained from the Secretary of the Society at the British Museum (Natural History), Cromwell Road, South Kensington, London, S.W.7.

\section{American Foreign Policy}

UNDER the title "American Foreign Policy" Prof. D. W. Brogan has given (Oxford Pamphlets on World Affairs, No. 50. 4d. net) a brilliant and concise interpretation of the traditional outlook of the United States on world affairs, the policy which she has followed in recent years and the machinery by which that policy is carried out. The pamphlet should make a valuable contribution to that mutual understanding by the two peoples upon which alone effective collaboration can be based. What Prof. Brogan has to say about the United States as a missionary of freedom and of American sympathy with democracy, no less than his explanation of the machinery of American foreign policy and of the real meaning of the Monroe doctrine, should go far to remove some of the difficulties which the ordinary citizen of Great Britain experiences in understanding, and still more in reconciling, the high moral line taken in foreign affairs by American public opinion, and the much more realistic attitude of the Administration. In this lucid account, written with admirable detachment, particular attention is given to the development of policy since 1918, including the "GoodNeighbour" policy, the reactions of the rise of Nazism and the collapse of France on the Monroe doctrine and its application or interpretation and the influence of the war debts on American opinion. Prof. Brogan has rendered real service to Anglo-American collaboration and all that it involves by this admirable exposition of the 'neutrality. legislation' and the factors weakening extreme isolationism and bringing the two democracies to such a declaration of common policy as that contained in the Atlantic Charter.

\section{The Genetical Society of Great Britain}

DuRnNe the first year of the War the British Genetical Society, which has a membership of 146 , held only its annual meeting. From the summer of 1941 it may be said, however, to have resumed its normal activities. Two meetings have been held, at the Rothamsted Experimental Station and at Oxford. On each occasion papers were read and members demonstrated a considerable series of exhibits. Although winter meetings are still impossible, it is hoped to commence a full programme next year with a meeting in the early spring. The present officers of the Society are: President, Prof. R. A. Fisher ; Vice-Presidents, Dr. C. D. Darlington, Prof. Julian Huxley, Dr. R. N. Salaman; Treasurer, E. R. Saunders ; Secretaries, Dr. K. Mather, Dr. E. B. Ford.

\section{Announcements}

According to a Dutch correspondent of The Times, the German authorities in Holland have closed the University of Leyden. After November 20 no examinations are being held there, but the students will be allowed to sit for examinations at other Netherlands universities, and will be admitted to German ones. Lectures at Leyden were discontinued a long time ago (see NATURE of February 8, p. 161).

THe following appointments in the Colonial Service have recently been made: E. D. Bumpus, agricultural superintendent, Nigeria; A. E. Kerr, assistant Government chemist, Trinidad; J. E. Cousens, assistant conservator of forests, Malaya; A. P. D. Jones, assistant conservator of forests, Nigeria ; J. J. Laurie, assistant conservator of forests, Gold Coast ; G. H. Thompson, assistant conservator of forests, Gold Coast; R. J. Osborne, surveyor, Uganda; D. Westwood, agricultural officer, Gold Coast; Dr. A. W. R. Joachim (agricultural chemist), divisional and research staff officer, Ceylon.

-A central sales branch has been organized for all work connected with subscriptions, sales and distribution of the journals and other publications of the majority of the Imperial Agricultural Bureaux ; its offices are at the Agricultural Research Building, Penglais, Aberystwyth. The only publications not dealt with by the central sales branch are those of the Imperial Institute of Entomology (Assistant Director, Imperial Institute of Entomology, 41, Queen's Gate, London, S.W.7) and the Imperial Mycological Institute (Director, Imperial Myeological Institute, Ferry Lane, Kew, Surrey), and Nutrition Abstracts and Reviews (Secretary, Imperial Bureau of Animal Nutrition, Rowett Institute, Bucksburn, Aberdeen). 